ECONOMIC THEMES (2019) 57(3): 307-327

DOI 10.2478/ethemes-2019-0018

\title{
REVEALED COMPARATIVE ADVANTAGES AND COMPETITIVENESS OF THE MANUFACTURING INDUSTRY OF THE REPUBLIC OF SERBIA
}

\section{Enes Ćorović}

State University of Novi Pazar, Department of economic sciences, Republic of Serbia

$\triangle$ enes.corovic@yahoo.com

\section{Živorad Gligorijević}

University of Niš, Faculty of Economics, Republic of Serbia

$\square$ zivorad.gligorijevic@eknfak.ni.ac.rs

\section{Aleksandar Manasijević}

Student at University of Niš, Faculty of Economics, Republic of Serbia $\triangle$ aleksandar.manasijevic.eknfak@gmail.com

UDC

330.34

(497.11)

Review paper

Received: 04.09.2019 Accepted: 28.11.2019

\begin{abstract}
The key research questions in this paper are related to determining the effects and impacts of a new economic growth model on the comparative advantages and competitiveness of exports of Serbian technological manufacturing product groups on the EU-28 market. The research used some of the analytical instruments of the methodology developed by the International Trade Center (ITC), as well as a modified RCA index. There was conducted a comparison of results of measuring export competitiveness using the methodology and RCA index according to the Balassa formula. All relevant analyses brought up similar conclusions regarding the modest effects of the reformed growth model, the low level of export competitiveness of medium and high technology products, but also regarding Serbia's lagging behind its competitors from the immediate surrounding and the world average. The results indicate that Serbia has failed to balance the structure of sources of financing for the new economic growth model, especially in terms of under-representation of domestic, public and private investments. They reflected on the low volume of gross investment, investment in industry in particular, their inadequate structure and the slow growth of export in production sectors, being the most affected by technological progress.
\end{abstract}

Keywords: manufacturing, RCA Index, technology groups, competitiveness, investment.

JEL classification: L52, L60 


\section{Introduction}

The success of structural adjustment process of non-market economies, no doubt, lies in the answer to the question: is the newly formed economic structure capable of producing autonomous economic growth on a market basis, with long-term and new development potentials? The economic crisis of 2008, i.e. its impact on economic developments in the Republic of Serbia, further intensified the effects of the existing economic development issues that had been accumulating for decades, so that the post-crisis period marked a new phase in the further process of structural transformation. The fact that Serbia was forced to change its growth model provides a clear answer to the initial dilemma (Gligorijević \& Ćorović, 2019, p. 91). Although Serbia's economy has moved from the lowest stage of competitiveness to the group of countries where competitiveness is based on the increase of the production processes' efficiency and product quality, due to the slow process of structural and institutional reforms, it has not been classified into economies whose growth is based on technological production innovations.

The reason for the low level of competitiveness is deep structural imbalances. However, it is certainly not possible to separate the analysis and open comparative advantages issue, and improving the competitiveness of the manufacturing industry from the fact that Serbia, as a part of the structural transformation process, did not have a long-term development strategy. Only under pressure of the effects of the crisis, at the beginning of 2011, there appeared a document for explicit formulation of all development policies, strategies and reforms, titled Strategy and Policy for Development of Industry of the Republic of Serbia from 2011 to 2020. (RS Official Gazette 55/2011).

The developmental goals of the Industrial Development Strategy of the Republic of Serbia from 2011 to 2020, have been derived from the newly proclaimed model of economic growth and development. The basic elements of this model are: industrial growth, based on the dynamic growth of investments in the manufacturing sector (key structural change), export orientation, primarily to the EU-28 market, dominated by the most propulsive industries, affected by rapid technological progress. The growth model was also based on the expectation of a large inflow of foreign direct investment, as the most efficient way of realizing these structural changes.

Based on the relevant knowledge about the slow course of structural changes in the Serbian manufacturing industry during the development strategy, the aim of the research in this paper is to point out the extremely modest effects of the reformed growth model, with a focus on the empirical analysis of open comparative advantages and flows of changes in the competitiveness of manufacturing technology groups of the Serbian industry on the EU-28 market. In analyzing the causes of these developments, the matter of successful implementation of other, certainly significant, elements of the new growth model is indispensable. 


\section{Research methodology}

An empirical analysis of open comparative advantages and flows of changes in the competitiveness of technology groups of Serbian manufacturing industry is based on the internationally accepted classification of branches and products according to the level of applied technology. The classification, which is based on direct R\&D intensity, embedded in consumer and investment goods, was first proposed by Hatzichronoglou (1997), when four categories were introduced: high, medium high, medium low and low technology. The definition has been updated in ISIC Rev.3, OECD (2003)

The classification based on direct R\&D intensity, was first published in the 2001 OECD Annex, along with data from OECD Science, Technology and Industry (STI). Updated calculations with identical results were published in the 2003 edition.

In accordance to the above mentioned, technology groups of manufacturing industry of the Republic of Serbia have the following composition:

1) low technology industries - production of food and beverages, tobacco, textile, clothing and leather, wood and paper products, printing, publishing and furniture production;

2) medium low technology industries - production of coke, oil and petroleum products, rubber and plastics, base metals, non-metals and metal products;

3) medium and high technology industries - production of chemical products, computers and communication devices, electrical equipment, motor vehicles and other means of transport. The merging of the last two technology groups was conveyed to align with international literature on this topic.

Extensive literature has been consulted to select the appropriate research methodology in this paper, as part of measuring competitiveness. Considering the aim of the research, i.e. the need to explicitly detect the reformed growth model's extent and dynamics of the impact on the change in the structure and competitiveness of certain branches, especially technology groups of the Serbian manufacturing industry, modified RCA index and some analytical instruments of the methodology developed by the International Trade Center (ITC), based in Geneva. These methodologies, in addition to producing the desired results, require more modest statistical resources and limited space for presentation of their processing.

Balassa (1965) derived the Index of revealed comparative advantage (RCA), which measures a country's comparative advantage in trade of a particular product / industry by determining the share of that product / industry in the country's total exports, relative to the share of that product / industry in total world exports. $\mathrm{He}$ suggested that an open comparative advantage is revealed by observing patterns of 
trade, so that the original RCA index is derived from the reference export data. According to this index of specialization, a sector of the national economy with a competitive advantage value exceeding 1 is a significant exporter and is assumed to be competitive.

For the specific needs of analyzing open comparative advantages, especially classified technology groups within the Serbian manufacturing industry, the authors modified the original RCA index, so that it presents the ratio of the relative share of exports of each technology group in total national exports to the EU-28 market and the relative share imports of a particular technology group in total import of products and a technology group from all over the world on the EU-28 market.

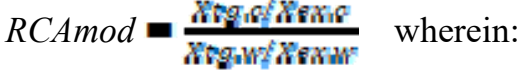

Xtg.c - exports of the country's technology group on the EU-28 market, Xex.c - total exports of the country on the EU-28 market, $X \operatorname{tg} . w$ - export of the world technology group to the EU-28 market and $X e x . w$ - total world exports to the EU-28 market.

As with the original RCA index, the technology group of the national economy, which has a value of discovered comparative advantages over 1 , is a significant exporter and is presumed to be competitive, while technology groups with a value below 1 are considered non-competitive.

The determination to explore the competitiveness of Serbia's manufacturing industry in the European Union market has necessitated the use of dynamic analytical instruments of the ITC (2000) methodology, derived from basic market share analysis, such as absolute change in the world market share and change in the world market share. Using these indicators, there were analyzed the absolute and relative changes in the share of export value of certain technology groups of Serbian manufacturing industry in the import of these goods into the EU - 28 market.

Using the modified RCA index and the mentioned instruments of the ITC methodology, the statistics for the period 2007-2018 were analyzed. The analyzed time series can be characterized as short, however, it should be acknowledged that the analysis is focused on the period after the economic crisis of 2008, when the reformed model of economic growth in the Republic of Serbia was also promoted. In doing so, there are sufficient relevant data to monitor competitiveness in the period before, during and after the aforementioned economic crisis. 


\section{Technical and technological progress, structural change and economic growth}

At the end of the 20th century, technical and technological progress was recognized as the most significant source of economic growth in the long run, from a global perspective.

Disruptions in the world economy during this period, combined with low growth rates, rising unemployment and inflation, point to structural weaknesses in industrial production, in both the most developed market economies and among planned economies (Gligorijević \& Ćorović. 2018 p.141). That was the factor that initiated an extensive process of structural change that, over the next forty years, would mark the changes in the structure of the entire global economy. By then, dominant, traditional industrial sectors, based on classic technology and large-scale capital investment, were beginning to see a slowdown in growth and employment. Increasing the competitive pressure from developing countries has led to a decline in the share of the most developed countries in international trade.

In response to such developments, as a product of intensive technical and technological progress in many manufacturing and service spheres, a wave of structural changes in the economies of developed countries was initiated, which resulted in the emergence of new industries, innovations in existing production processes, new products and technologies. Along with these changes, in order to increase the efficiency of their functioning, the planned economies were forced to start the transition process towards the construction of market systems. (Ćorović, 2012 p. 77)

During these development processes, several dominant facts emerged to describe how technology and innovation generate economic growth and development (UNIDO. 2016 p. 49). The first one is related to different innovation capabilities, as well as opportunities to use new technologies in highly developed and developing countries. By initiating structural changes, primarily in the manufacturing industry sector, these differences determine the higher or lower level of economic performance of those countries in the long run.

Innovation and technology are not public goods and do not spread freely or simultaneously around the world. Structural transformations, leading to take-offs and sustainable growth, are very difficult to implement, as they require significant resources and concentrated effort from many economic and social actors. Countries that are already at a high level of development usually have high capacity to innovate and independently generate technical and technological progress. This gives them a monopoly position in the economic exploitation of these acquired advantages in the development of highly competitive manufacturing sectors and the international trade in high technology products. In other words, the level of innovation ability and development mutually affect each other. (Fagerberg \& Srholec, 2008) 
With regard to developing countries, which lack the innovation capability and invest much less in R\&D, one type of gradual innovation deserves special attention. It is the acquisition and imitation of technological knowledge from abroad. When a new product or process diffuses into developing countries, it is, by definition, an innovation and usually requires considerable effort and ability to adapt to local conditions. In doing so, imitation and adaptation of technologies, originating from more industrialized countries, is one of the biggest sources of economic growth and ways to catch up. However, such an adaptation requires certain technological capacities.

The technology gap theory comprehensively shows that economic development, on the one hand, is driven by the international spread of technological knowledge, while on the other, it is made possible by the development of the capacities of economic participants (actors) who adopt that knowledge, as well as by the development of institutions that facilitate its adoption and application. This theory was first introduced by Abramovitz (1986), Fagerberg (1987) and Verspagen (1991).

Another fact that has established itself in international trade over the past decades has been a good path to distinguish between fast-growing and slowgrowing countries. In other words, the capabilities that enable a country to keep pace with global technical and technological trends are closely linked to its export competitiveness on the global market. Globalization offers opportunities to overcome technological lag of developing countries through the diffusion of knowledge. However, opening up the economy to global markets does not automatically lead to growth.

Since 2001, the share of production for foreign final demand has grown steadily. With this in mind, the third fact, regarding the use of export markets as means of economic growth, requires that companies move to a new product category of greater complexity, which implies the application of new technology in the production process.

The best evidence of a change in the structure of global production is the shift of the focus of industry from low-tech to medium-high and high-tech activities. In 2015 , the medium and high-tech sectors accounted for $44.7 \%$ of the world added value, while in 2005 their relative share was 32.3\%. (UNIDO. 2018 p. 166) In addition, the share of highly developed countries in global value-added production fell from $78.5 \%$ in 2005 to $65.4 \%$ in 2015 , while in developing countries, in the same period, increased from $21.5 \%$ to $34.6 \%$ (UNIDO. 2018 p. 167).

Global exports from 2000 to 2015 had a high average annual growth rate of $6.5 \%$. Developing countries have been the ones who made the largest contribution to the development of international trade. (UNIDO. 2018 p. 170-172). The average annual growth rate of their exports during this period was $11.7 \%$, while the 
developed countries recorded an average growth of goods exports of $4.8 \%$. Manufacturing exports accounted for $88.6 \%$ of global merchandise exports in 2015 .

Commodity exports suffered a sharp decline in 2008 in almost all groups of countries. In the aftermath of the economic crisis, the trend of global export growth slowed down, mainly as a result of the slowdown in economic growth in China and other fast-growing economies. This has also led to a slowdown in structural changes in the technological structure of commodity exports. (Table 1)

Table 1: Export structure of manufacturing industry by technology groups in the world, industrialized countries and developing countries (\%) of total world exports

\begin{tabular}{||l|l|l|l|l|l|l||}
\hline Technology group / region & $\mathbf{2 0 1 0}$ & $\mathbf{2 0 1 1}$ & $\mathbf{2 0 1 2}$ & $\mathbf{2 0 1 3}$ & $\mathbf{2 0 1 4}$ & $\mathbf{2 0 1 5}$ \\
\hline Low technology & & & & & & \\
\hline World & 19,1 & 19,4 & 19,2 & 19,4 & 20,1 & 20,4 \\
\hline Industrialized countries & 10,5 & 10,3 & 9,9 & 10,0 & 10,3 & 10,0 \\
\hline Countries in development & 8,6 & 9,1 & 9,3 & 9,4 & 9,8 & 10,4 \\
\hline Middle lower technology level & & & & & & \\
\hline World & 21,3 & 22,8 & 23,4 & 23,5 & 22,0 & 19,7 \\
\hline Industrialized countries & 14,4 & 15,6 & 16,0 & 16,5 & 15,1 & 13,3 \\
\hline Countries in development & 6,9 & 7,2 & 7,4 & 7,0 & 6,9 & 6,4 \\
\hline Intermediate upper and high level technology & & & & & & \\
\hline World & 59,6 & 57,8 & 57,4 & 56,9 & 57,9 & 59,9 \\
\hline Industrialized countries & 38,2 & 36,8 & 35,4 & 34,4 & 35,8 & 38,4 \\
\hline Countries in development & 21,4 & 21,0 & 22,0 & 22,5 & 22,1 & 21,5 \\
\hline
\end{tabular}

Source: Authors calculations based on data: UNIDO, Industrial Development Report 2018, Vienna, p. 203-204.

In the period after 2010, exports of medium and high-tech products continued to dominate the international trade. After a four-year decline, below $58 \%$ of total world exports, in 2015 this technology group regained its stake at around 60\%. Highly developed countries account for almost two-thirds of the exports of these products. Likewise, in the commodity exports of developing countries, this technology group of products has a stable share, with $21.5-22.5 \%$ of world exports.

In international trade, exports of low-tech products have seen a slight rise, due to an increase in the relative share of developing countries from $8.6 \%$ to $10.4 \%$ in the observed period. The industrialized countries in this technology group, as well as in the export of medium-low technology products, show a slight decline in the relative share in world exports. This trend can also be observed in developing countries, so that exports of the whole group of medium-tech products are in relative decline.

\section{Performance of Serbia's foreign trade after the economic crisis}

After a drastic downfall in 2008, Serbia's exports are recovering rapidly, both on the EU-28 and global markets. Between 2010 and 2018, merchandise exports 
towards the world grew dynamically at an average annual rate of $10.6 \%$. In the same period, exports to EU countries, despite the slow recovery of this large market, as a result of the global crisis, had an average annual growth of $12.1 \%$. At the same time, the average annual growth rate of total Serbian imports was at the level of $7.1 \%$, while imports from the EU countries increased at an average rate of $7.4 \%$ (Table 2).

Table 2: Volume, dynamics and regional structure of the foreign trade of the Republic of Serbia economy from 2010 to 2018 (in millions of euros)

\begin{tabular}{||l|c|c|c|c|c|c|c|c|c||}
\hline Description & $\mathbf{2 0 1 0}$ & $\mathbf{2 0 1 1}$ & $\mathbf{2 0 1 2}$ & $\mathbf{2 0 1 3}$ & $\mathbf{2 0 1 4}$ & $\mathbf{2 0 1 5}$ & $\mathbf{2 0 1 6}$ & $\mathbf{2 0 1 7}$ & $\mathbf{2 0 1 8}$ \\
\hline Export Serbia - World & 7376 & 8457 & 8731 & 10999 & 11166 & 12053 & 13405 & 15012 & 16280 \\
\hline Import Serbia - World & 12602 & 14260 & 14750 & 15472 & 15503 & 16405 & 17363 & 19603 & 21916 \\
\hline Export Serbia - EU & 4459 & 5211 & 5360 & 6900 & 7216 & 7919 & 8867 & 9920 & 10909 \\
\hline Import Serbia - EU & 7374 & 8266 & 8967 & 9582 & 9779 & 10236 & 10944 & 12222 & 13227 \\
\hline $\begin{array}{l}\text { \% of export Serbia } \\
\text { EU/World }\end{array}$ & 60,4 & 61,6 & 61,3 & 62,7 & 64,6 & 65,7 & 66,1 & 66,0 & 67,0 \\
\hline $\begin{array}{l}\text { \% import Serbia } \\
\text { EU/World }\end{array}$ & 58,5 & 57,9 & 60,7 & 61,9 & 63,0 & 62,3 & 63,0 & 62,3 & 60,3 \\
\hline $\begin{array}{l}\text { Export growth rate } \\
\text { Serbia - World }\end{array}$ & 15 & 3 & 26 & 2 & 8 & 11 & 11 & 12 & 8 \\
\hline $\begin{array}{l}\text { Import growth rate } \\
\text { Serbia - World }\end{array}$ & 13 & 3 & 5 & 0 & 6 & 6 & 6 & 13 & 12 \\
\hline $\begin{array}{l}\text { Export growth rate } \\
\text { Serbia - EU }\end{array}$ & 17 & 3 & 29 & 5 & 10 & 12 & 11 & 12 & 10 \\
\hline $\begin{array}{l}\text { Import growth rate } \\
\text { Serbia - EU }\end{array}$ & 12 & 8 & 7 & 2 & 5 & 7 & 6 & 12 & 8 \\
\hline $\begin{array}{l}\text { Manufacturing industry } \\
\text { export Serbia - EU }\end{array}$ & 4010 & 4479 & 4596 & 6163 & 6850 & 7507 & 8470 & 9600 & 10471 \\
\hline $\begin{array}{l}\text { \% of manufacturing } \\
\text { industry export/total } \\
\text { export - Serbia }\end{array}$ & 90 & 86 & 86 & 89 & 95 & 95 & 96 & 96 & 96 \\
\hline
\end{tabular}

Source: Author's calculations based on data www.intracen.org: Trade statistics International trade center, Website visited: 02.06.2019.

The foreign trade deficit with the world was reduced from EUR 5.226 billion in 2010 to EUR 4.591 billion in 2017. At the same time, the share of exports in gross domestic product increased from $33 \%$ in 2010 to $38.3 \%$ in 2017. (National Bureau of Statistics, 2018)

In the last two years, there has been a faster growth of goods imports than exports of Serbia, especially from the global market. The period is too short to discuss a trend of widening external imbalance, which is related to consumption growth. Moreover, given the fact that the largest import growth items are related to the increase of crude oil prices on the world market (an increase of $65.9 \%$ or EUR 1009 million from 2016 to 2018), more extensive imports of electrical equipment (growth $56,2 \%$ or $€ 746$ million), machinery and machine assemblies (up $43.8 \%$ or $€ 585$ million). (www.intracen.org: Trade statistics - International trade center). The key contribution to reducing Serbia's external imbalance was made by the 
manufacturing industry, whose share in total exports from $90 \%$ in 2010, increased to $96 \%$ in 2016 . In doing so, the question arises: what factors have predominantly influenced the more favorable flows in Serbia's foreign trade since 2010, and to what extent is it the contribution of economic policy and the new growth model?

Positive flows towards reducing the external imbalance are, for the most part, a consequence of the slowdown in Serbia's post-crisis imports. Basically, it is a changed correlation of the ratio between the growth of gross domestic product and aggregate demand, especially final consumption. The stabilization of this trend, in terms of public spending, was followed by the successful implementation of fiscal consolidation measures from the beginning of 2015 onwards. (Gligorijević \& Ćorović, 2018 p. 247). Key effects have been achieved by activating foreign direct investment previously received, especially in the automotive industry, the production of electrical equipment, rubber and plastics. Measures for attracting new, especially green field investments had more visible success in 2017.

The regional structure of Serbia's exports has changed significantly since the beginning of the global crisis. Namely, by 2009 , on average, $55 \%$ of Serbia's exports were realized in the region of the European Union. The CEFTA countries, mainly the former Yugoslav republics, were the second important market. It accounted for over $30 \%$ of Serbia's exports. In addition to an exceptional customs relief, the exports to Russia and other CIS countries were very modest. After 2010, the largest growth was recorded in exports to the EU countries, which exceeded $66 \%$ of total exports, with a slightly lower relative share of exports to CEFTA countries. In terms of imports from the EU countries after 2010, the change in relative share took place at the same pace as it did for exports. In 2016, it reached $63 \%$ of total imports. In addition to the extremely slow growth of the manufacturing industry in the period after 2010, exports to the EU-28 market, as well as total exports, recorded positive changes in the technological structure (Table 3).

Table 3: Export structure of Serbian manufacturing industry by technology groups (in\% of total exports)

\begin{tabular}{||l|l|l|l|l|l|l||}
\hline Technology group & $\mathbf{2 0 1 0}$ & $\mathbf{2 0 1 1}$ & $\mathbf{2 0 1 2}$ & $\mathbf{2 0 1 3}$ & $\mathbf{2 0 1 4}$ & $\mathbf{2 0 1 5}$ \\
\hline Low technology & & & & & & \\
\hline Serbia & 29,9 & 33,6 & 30,9 & 26,3 & 26,8 & 28,2 \\
\hline Middle lower technology level & & & & & & \\
\hline Serbia & 39,2 & 40,5 & 32,6 & 26,6 & 29,1 & 28,0 \\
\hline Middle higher and high technology level & & & & & & \\
\hline Serbia & 30,9 & 25,9 & 36,5 & 47,1 & 44,1 & 43,8 \\
\hline
\end{tabular}

Source: Author's calculations based on data www.intracen.org: Trade statistics International trade center. Website visited: May $4^{\text {th }}, 2019$.

While in the period until 2015, the relative share of exports of medium and high-tech products has increased from $30.9 \%$ to $43.8 \%$, the exports classified in lower technology groups have been both growing and declining in cycles. 
However, despite the positive trend, changes in Serbia's export structure do not follow the dynamics of global changes (Table 1). In the same period, the world average of the relative share of exports of medium and high-tech products was $15 \%$ higher.

\section{Analysis of the competitiveness of Serbian manufacturing industry on the EU market using the instruments of the ITC methodology}

The instruments selected by the ITC methodology for determining the level and changes in the competitiveness of individual branches, technology groups and the entire Serbian manufacturing industry are based, primarily, on the analysis of their market share trends in imports on the European Union market. In this regard, data on exports for the period from 2010 to 2018, as well as data on imports to that market, are analyzed for all branches of the manufacturing industry, as well as for the individual technology groups.

The determination to explore the competitiveness of Serbian manufacturing industry technology groups, in the context of contemporary changes in the global, and especially the European Union market, has necessitated the use of dynamic analytical instruments, derived from the so-called market share analysis, such as absolute change of the market share and change in the market share. Using these indicators, there were analyzed the absolute and relative changes in the share of the value of Serbia's manufacturing exports in the import of these goods to the European Union market (EU-28), which is by far the most significant for this sector of the Serbian economy.

The analysis of the market share of the Serbian manufacturing industry indicates the marginal impact of individual branches (maximum $0.43 \%$ ), technology groups (maximum $0.26 \%$ ) and total exports (maximum $0.18 \%$ ) of this part of the Serbian economy, on the economic flows of the European Union. This impact is somewhat more significant only in the group of individual products or product groups, the so-called "export stars", although the key value of this instrument lies in the dynamic nature of competitive flows. From this point of view, the results of the analysis are significantly more positive.

From the aspect of quality of growth of competitiveness of Serbian manufacturing industry, the key question relates to the structure of the market share of those branches of industry that have achieved growth, due to their technological level. Depending on industry classification, based on ISIC Rev. 3 (United Nations Statistics Division, 2002), and according to the technology classification in the production of OECD values (2003), industries are divided into branches of low, medium low, medium high and high technology. In the observed period, the group of medium and high technology recorded both absolute and relative growth of market share (Table 3). The highest growth is shown by the medium and high 
technology group, with absolute growth of $0.11 \%$ and relative growth of market share of $157 \%$ on the EU-28 market. This is, without a doubt, a key indicator of the positive changes in Serbia's export structure, which has been gaining momentum since 2010 .

Table 4: Absolute and relative market share growth of technology groups Serbian manufacturing industry on the EU-28 market

\begin{tabular}{||l|c|c|c|c|c|c||}
\hline Market share growth & $\begin{array}{c}\text { Absolute } \\
\text { growth } \\
\mathbf{2 0 0 7 -} \\
\mathbf{2 0 1 0}\end{array}$ & $\begin{array}{c}\text { Absolute } \\
\text { growth } \\
\mathbf{2 0 1 0 -} \\
\mathbf{2 0 1 8}\end{array}$ & $\begin{array}{c}\text { Absolute } \\
\text { growth } \\
\mathbf{2 0 0 7 -} \\
\mathbf{2 0 1 8}\end{array}$ & $\begin{array}{c}\text { Relative } \\
\text { growth } \\
\mathbf{2 0 0 7 -} \\
\mathbf{2 0 1 0}\end{array}$ & $\begin{array}{c}\text { Relative } \\
\text { growth } \\
\mathbf{2 0 1 0 -} \\
\mathbf{2 0 1 8}\end{array}$ & $\begin{array}{c}\text { Relative } \\
\text { growth } \\
\mathbf{2 0 0 7 -} \\
\mathbf{2 0 1 8}\end{array}$ \\
\hline Low technology & 0,01 & 0,10 & 0,11 & 0,06 & 0,62 & 0,73 \\
\hline Medium low technology & $-0,02$ & 0,07 & 0,05 & - & 0,47 & 0,29 \\
\hline $\begin{array}{l}\text { Medium and high } \\
\text { technology }\end{array}$ & 0,02 & 0,11 & 0,13 & 0,4 & 1,57 & 2,60 \\
\hline
\end{tabular}

Source: Author's calculations based on data: www.intracen.org: Trade statistics International trade center. Website visited: 05.05.2019.

Significant relative growth in market share is also achieved by products of low technological level $-62 \%$, but with slower dynamics than the growth of total exports and exports to the EU-28 market. In the forthcoming period, the growth of medium-low tech products is expected to accelerate, due to successful privatizations in the production of base metals and the continued growth of rubber and plastic products. However, despite the positive dynamic indicators of the change in the export structure of the manufacturing industry, the current crosssection indicates a low level of its competitiveness.

The dominant market share in the export structure of this sector of industry (EU market) is the low and medium-low technology groups $-0.26 \%$ and $0.22 \%$, respectively, in 2018. Although exports of medium and high-tech products in absolute terms lead in value, they show the least market share $-0.18 \%$. - which is an indicator of low competitiveness (Table 4).

Table 5: Market share of technology roups of Serbian manufacturing industry on the EU-market of the same groups in \%

\begin{tabular}{||l|c|c|c|c|c|c||}
\hline \hline PRODUCTS & $\mathbf{2 0 1 0}$ & $\mathbf{2 0 1 1}$ & $\mathbf{2 0 1 3}$ & $\mathbf{2 0 1 5}$ & $\mathbf{2 0 1 7}$ & $\mathbf{2 0 1 8}$ \\
\hline Low technology & 0,16 & 0,18 & 0,20 & 0,23 & 0,26 & 0,26 \\
\hline Medium low technology & 0,15 & 0,14 & 0,12 & 0,17 & 0,21 & 0,22 \\
\hline $\begin{array}{l}\text { Medium high and high } \\
\text { Technology }\end{array}$ & 0,07 & 0,06 & 0,15 & 0,14 & 0,17 & 0,18 \\
\hline
\end{tabular}

Source: Author's calculations based on data www.intracen.org: Trade statistics International trade center, Website visited: 02.06. 2019.

This situation is a consequence of extensive foreign direct investment in Serbia in the production of automobiles and electrical equipment, whose contribution to 
exports is, in absolute terms, the foremost. The continuation of such a positive trend will be in function of the ability of economic policy and executive authorities to stimulate the dynamic influx of high-tech investments, with the continued growth of production of the aforementioned industries.

\section{Comparative advantages discovered - RCA index by technology groups of Serbian manufacturing industry}

As pointed out in the methodological part of this paper, the original index revealed comparative advantage - RCA, by the Balassa formula, compares the share of the value of exports of the observed sector in national exports and the share of the value of exports of that sector globally or regionally, in relation to the total regional or world export. According to the defined research objective, the authors modified the original RCA index, so it represents the ratio of the relative share of exports of each processing industry group in total national exports to the EU-28 market and the relative share of imports of that technology group in total product imports and from around the world on the EU-28 market. As with the original formula, the technology group of the national economy, which has a value of discovered comparative advantages over 1 , is a significant exporter and is assumed to be competitive and below 1 to be non-competitive.

The modification of the original methodology of measuring national competitiveness, not only gives a specific angle of observation of this phenomenon, but reveals the directions and dynamics of structural changes in a national economy, in comparison to global flows. In addition, the observed differences in the results obtained by applying two different variants of the RCA index, more precisely identify the weaknesses of the growth model in the particular case.

This methodology of measuring macro-competitiveness has a significant place in international literature in comparative analyses of national competitiveness of individual countries: Japan and the USA (Balassa \& Noland, 1989), Southeast Asian countries (Reza, 1983), Turkey, Bulgaria, Czech Republic, Hungary, Poland and Romania ( Y1lmaz, 2003). In the analysis of sub-sectoral competitiveness, the analysis of the competitiveness of the agri-food industry in Hungary deserves attention (Fertő \& Hubbard, 2002). A similar methodological approach to modifying the original RCA index formula was applied in the analysis of export competitiveness of certain technology groups of Turkish products (Topcu \& Klavuz, 2012).

In addition to 2007, the index revealed comparative advantage - RCA, for the entire manufacturing industry, shows a positive value (around 1) and from 2014 onwards. The value of the RCA index has been negative continuously from 2008 to 2013 (except 2012). Therefore, considering the established values of exports, the 
period after the economic crisis in Serbia can only be discussed since 2014. The trend in the value of the RCA index after the economic crisis indicates a slow structural change in the direction of increasing the share of manufacturing in gross domestic product and very modest effects of the announced growth model reform. (Gligorijević \& Ćorović. 2019, p.158)

In addition, the movement of this indicator, which gives a global dimension to national competitiveness and the direction of specialization of its industrial structure, is significantly different from changes in the market share of individual branches and the entire Serbian manufacturing industry on the EU-28 market. The differences are apparent during and after the crisis. The RCA index shows a decrease in competitiveness during the crisis period (2008-2009), but also in the period after the crisis of 2010, 2011 and 2013 (RCA value below 1), while in the period of absolute growth of Serbia's exports (from 2014), this index does not show any significant increase in competitiveness (value around 1) (Gligorijević \& Ćorović. 2019, p.159).

During and immediately after the crisis, there were no significant changes in the market share of this sector of the Serbian economy on the EU-28 market. These differences can be partly explained by the high orientation of Serbia's exports to the EU-28 market, but also by the slower recovery of this market, in comparison to global flows in the post-crisis period.

The application of the modified RCA index formula, which focuses on changes in the technological structure of Serbia's exports and the competitiveness of certain technology groups of production branches, gives a different picture of changes in the competitiveness of exports of our manufacturing industry in the EU-28 market, compared to the first two methodologies (Table 6).

Table 6: RCA index of Serbia's manufacturing industry on the EU-28 market by technology groups

\begin{tabular}{||l|c|c|c|c|c|c|c||}
\hline PRODUCTS & $\mathbf{2 0 0 7}$ & $\mathbf{2 0 0 9}$ & $\mathbf{2 0 1 0}$ & $\mathbf{2 0 1 1}$ & $\mathbf{2 0 1 3}$ & $\mathbf{2 0 1 6}$ & $\mathbf{2 0 1 8}$ \\
\hline Low technology & 1,50 & 1,57 & 1,41 & 1,63 & 1,33 & 1,35 & 1,19 \\
\hline Medium low technology & 1,68 & 1,34 & 1,36 & 1,26 & 0,82 & 1,00 & 1,04 \\
\hline $\begin{array}{l}\text { Medium high and high } \\
\text { technology }\end{array}$ & 0,45 & 0,56 & 0,61 & 0,54 & 0,98 & 0,86 & 0,87 \\
\hline
\end{tabular}

Source: Author's calculations based on data www.intracen.org: Trade StatisticsInternational trade center. Website visited: 10.06.2019.

Firstly, the obtained results suggest that the absolute and relative growth of market share, both of individual sectors and the entire manufacturing industry, is not sufficient to increase the competitiveness of our exports. Throughout the period under review, the more competitive segments of Serbia's exports, the low and medium-low tech product groups, have a marked downward trend in competitiveness. In 2018, the modified RCA index indicates a positive competitive 
edge. At the same time, the export segment of medium and high-tech products has negative values throughout the observed period, with a growing trend of competitiveness.

Secondly, unlike the results of the original formula of the RCA index, in 2007, as well as after 2014, a significant part of our exports show signs of noncompetitiveness, but with a tendency of improving (medium and high technology group), while, during the same period, other technology groups have indicated the tendency to decline in competitiveness.

Thirdly, the obtained results are the exact opposite to the movement of the Global Competitiveness Index (GCI) from 2016 onwards (World Economic Forum, 2018), which shows a significant increase in Serbia's competitiveness. Obviously, the RCA index is a better indicator than an indicator of potential process marked by GCI index. (Gligorijević \& Ćorović. 2019 p. 160)

The analysis of the open comparative advantages and competitiveness of Serbia's manufacturing industry exports to the European Union market indicates serious shortcomings in the dynamics and technological structure of growth of this sector of our economy, as well as the modest effects of its newly proclaimed model. According to clear indications from the previous research, the key causes of these development problems are related to the broader complex of problems of financing our economic growth, and in particular to the volume and structure of industrial investments in Serbia. (Ćorović, 2019)

\section{Investments and changes in export technological structure of Serbian manufacturing industry}

The main shortcomings of the Strategy and Policy for the Development of Industry of the Republic of Serbia, for the period 2011-2020, are related to the unrealistic estimation projection of investment movements at the level of $25 \%$ of gross domestic product in the projected period. With an average of $18.8 \%$ in the observed period, Serbia is far below the level of investment in the Western Balkans (World Bank, 2017), Albania 27.9\%, Bosnia and Herzegovina 22.7\% and Croatia 25.5\%; and especially Eastern European countries that became EU members: Hungary $23.6 \%$, Slovakia $25.0 \%$ or globally $23.6 \%$. The reasons were numerous, but also predictable.

In the context of economic instability, in the aftermath of the economic crisis, both on the domestic and EU markets, it was unrealistic to project a steady inflow of foreign direct investment, averaging $€ 2.3$ billion a year, as a key source of financing economic growth and development.

The neglect of other sources of financing, without serious economic policy incentives, resulted in an average share of investments in gross domestic product of 
$18.8 \%$. The real average annual inflow of foreign direct investment in the amount of $€ 1.876$ billion in the post- 2010 period, which averaged $4.9 \%$ of GDP, was well below projections. The result is an extremely modest GDP growth of $0.77 \%$ per year, well below the projected 5.8\% per year. (Gligorijević \& Ćorović. 2019, p. 188-189)

When analyzing the structure of foreign direct investment, their orientation in the industry sector was $41.3 \%$, or EUR 775 million annually, which is absolutely not sufficient for more serious structural changes in the formation of gross domestic product (National Bank of Serbia - Statistics 2017).

Given the low growth of gross domestic product and the unfavorable structure of foreign direct investment, it was not possible to achieve higher average annual growth of the manufacturing industry of $2.8 \%$, which is far below the projected $7.3 \%$. The result is many times lower production per capita than in Croatia, Bulgaria, Hungary and Romania (Table 7). Therefore, the market share of Serbia's exports to the EU market is marginal.

Table 7: Competitiveness Indicators of Industrial Performance of Serbia and Neighboring Countries

\begin{tabular}{||l|c|c|c|c|c|c|c|c|c||}
\hline \hline Country & \multicolumn{3}{|c|}{$\begin{array}{c}\text { The added value of } \\
\text { manufacturing } \\
\text { industry } \\
\text { per capita } \\
\text { (\$ 2010 permanent) }\end{array}$} & \multicolumn{2}{c|}{$\begin{array}{c}\text { Medium high and high } \\
\text { technology production } \\
\text { share value added } \\
\text { in value of the whole } \\
\text { manufacturing industry } \\
\text { (percentage, current \$) }\end{array}$} & $\begin{array}{c}\text { The share of exports of } \\
\text { medium high and high } \\
\text { technological production } \\
\text { in the total export of } \\
\text { manufacturing industry } \\
\text { (percent, current \$) }\end{array}$ \\
\hline & $\mathbf{2 0 0 8}$ & $\mathbf{2 0 1 0}$ & $\mathbf{2 0 1 5}$ & $\mathbf{2 0 0 8}$ & $\mathbf{2 0 1 0}$ & $\mathbf{2 0 1 5}$ & $\mathbf{2 0 0 8}$ & $\mathbf{2 0 1 0}$ & $\mathbf{2 0 1 5}$ \\
\hline Serbia & 405 & 594 & 644 & 20,1 & 18,64 & 23,91 & 32,2 & 32,82 & 46,54 \\
\hline Croatia & 1661 & 1673 & 1636 & 31,8 & 37,55 & 29,94 & 49,6 & 49,46 & 45,31 \\
\hline $\begin{array}{l}\text { Northern } \\
\text { Macedonia }\end{array}$ & 474 & 450 & 629 & 13,7 & 19,5 & 15,35 & 29,6 & 31,42 & 58,88 \\
\hline Albania & 213 & 249 & 273 & 14,1 & 6,54 & 6,69 & 14,3 & 15,42 & 9,07 \\
\hline Bulgaria & 675 & 781 & 980 & 29,3 & 24,7 & 29,97 & 32,4 & 35,4 & 42,20 \\
\hline Romania & 829 & 1464 & 1909 & 28,3 & 40,15 & 37,85 & 37,0 & 54,69 & 58,20 \\
\hline Hungary & 2375 & 2385 & 2670 & 52,0 & 56,13 & 58,78 & 77,4 & 77,63 & 76,60 \\
\hline $\begin{array}{l}\text { Bosnia and } \\
\text { Herzegovina }\end{array}$ & 341 & 487 & 527 & 14,9 & 16,14 & 17,55 & 25,4 & 23,0 & 24,87 \\
\hline
\end{tabular}

Source: UNIDO, Industrial Development Report 2016, 2018, Vienna, p. 224-227.

In addition to the low volume of value added production per capita, which is the main source of low export competitiveness, Serbia's manufacturing industry also has a less favorable technological structure of value added production, than its first competitors.

While in 2015, the relative share of the value added of medium-high and high tech production in Serbia was $23.91 \%$, among competitors it ranged from around 
$30 \%$ in Croatia and Bulgaria, up to $58.78 \%$ in Hungary. Accordingly, the technological structure of exports is less favorable than that of Hungary and Romania.

Not only did the new growth model bring more investment to Serbia, but also the dynamics of changing their technological structure was slow and insufficient to accelerate the competitive advantages of exports (Table 8).

The relative increase in the share of investments in the mid and high-tech industries is more likely due to the slowdown in investment in the low-tech segment (especially in food production), as well as in the mid-low (especially coke production and oil derivatives).

In the observed period, their share is not only in relative decline (from $78.6 \%$ in 2010 , to $68.1 \%$ in 2016), but also, from year to year, it records an absolute decline.

Table 8: Gross investments in fixed assets in the Republic of Serbia, by industry and technology groups from 2010 to 2016 in millions of euros

\begin{tabular}{|l|c|c|c|c|c|c|c|c||}
\hline $\begin{array}{l}\text { Industry / Technology } \\
\text { Group }\end{array}$ & $\mathbf{2 0 1 0}$ & $\mathbf{2 0 1 1}$ & $\mathbf{2 0 1 2}$ & $\mathbf{2 0 1 3}$ & $\mathbf{2 0 1 4}$ & $\mathbf{2 0 1 5}$ & $\mathbf{2 0 1 6}$ & Total \\
\hline Low technology & $\mathbf{4 3 6}$ & $\mathbf{3 4 4}$ & $\mathbf{4 8 4}$ & $\mathbf{4 0 7}$ & $\mathbf{3 1 3}$ & $\mathbf{3 5 4}$ & $\mathbf{4 0 1}$ & $\mathbf{2 7 3 9}$ \\
\hline $\begin{array}{l}\text { Food industry, beverages } \\
\text { and tobacco }\end{array}$ & 340 & 275 & 271 & 274 & 208 & 238 & 282 & 1888 \\
\hline $\begin{array}{l}\text { Production of textiles and } \\
\text { clothing }\end{array}$ & 17 & 24 & 105 & 33 & 52 & 60 & 50 & 341 \\
\hline $\begin{array}{l}\text { Wood processing, paper } \\
\text { and print }\end{array}$ & 79 & 45 & 108 & 100 & 53 & 56 & 69 & 510 \\
\hline Medium low technology & $\mathbf{3 2 6}$ & $\mathbf{6 3 7}$ & $\mathbf{6 3 6}$ & $\mathbf{6 1 5}$ & $\mathbf{2 7 9}$ & $\mathbf{3 1 7}$ & $\mathbf{2 8 5}$ & $\mathbf{3 0 9 5}$ \\
\hline $\begin{array}{l}\text { Production of coke and } \\
\text { refined petroleum products }\end{array}$ & 127 & 363 & 387 & 392 & 5 & 5 & 2 & 1281 \\
\hline $\begin{array}{l}\text { Rubber and plastic } \\
\text { processing }\end{array}$ & 57 & 71 & 75 & 99 & 118 & 152 & 113 & 685 \\
\hline $\begin{array}{l}\text { Production and processing } \\
\text { of metal }\end{array}$ & 90 & 166 & 128 & 83 & 127 & 127 & 121 & 842 \\
\hline Production of nonmetals & 52 & 37 & 46 & 41 & 29 & 33 & 49 & 287 \\
\hline $\begin{array}{l}\text { Medium high and high } \\
\text { technology }\end{array}$ & $\mathbf{2 0 7}$ & $\mathbf{3 6 6}$ & $\mathbf{2 2 6}$ & $\mathbf{3 7 7}$ & $\mathbf{2 1 6}$ & $\mathbf{2 0 7}$ & $\mathbf{3 2 1}$ & $\mathbf{1 9 2 0}$ \\
\hline $\begin{array}{l}\text { Production of chemical and } \\
\text { pharmaceutical products }\end{array}$ & 65 & 79 & 83 & 129 & 110 & 98 & 199 & 763 \\
\hline $\begin{array}{l}\text { Production of computer } \\
\text { and electronic equipment }\end{array}$ & 46 & 60 & 65 & 57 & 42 & 37 & 40 & 347 \\
\hline $\begin{array}{l}\text { Production of motor } \\
\text { vehicles and trailers }\end{array}$ & 96 & 227 & 78 & 191 & 64 & 72 & 82 & 1157 \\
\hline Total by years & $\mathbf{9 6 9}$ & $\mathbf{1 3 4 7}$ & $\mathbf{1 3 4 6}$ & $\mathbf{1 3 9 9}$ & $\mathbf{8 0 8}$ & $\mathbf{8 7 8}$ & $\mathbf{1 0 0 7}$ & $\mathbf{7 7 5 4}$ \\
\hline
\end{tabular}

Source: Author's calculations based on data of the Republic Institute for Statistics Statistical Yearbook 2012-2018. 
Similar flows were recorded in changes in the structure of foreign direct investment in Serbia in the period after 2010. A simple insight into the technological level of foreign direct investment in the period until 2017 (Table 9), clearly illustrates the fact that foreign investors are oriented towards investing in the low and medium-low technological level of newly installed capacities in our country. Foreign direct investment in medium and high-tech manufacturing levels, with $21.4 \%$ in 2010 , increased to $31.8 \%$ relative share in the total volume of this external financing source in 2017.

It turns out that the key factors for attracting them are still low labor costs, government incentives and a convenient geo-strategic position. The often-argued argument for rapid structural change in a number of state development documents - the abundance of a well-educated workforce - has been seriously questioned during a period of structural transformation. The present fact of high levels of structural unemployment and an acute shortage of both highly educated technical staff for many industries and high-skilled craftsmen profiles, announces serious development problems in this area.

Table 9 Foreign direct investments in the Republic of Serbia, net liabilities, by activities and technology groups of manufacturing industry from 2010-2017 in millions of euros

\begin{tabular}{||l|c|c|c|c|c|c|c||}
\hline Technology group & $\mathbf{2 0 1 0}$ & $\mathbf{2 0 1 1}$ & $\mathbf{2 0 1 3}$ & $\mathbf{2 0 1 4}$ & $\mathbf{2 0 1 5}$ & $\mathbf{2 0 1 7}$ & Total \\
\hline Low technology & 68 & 288 & 238 & 190 & 211 & 143 & $\mathbf{1 4 6 6}$ \\
\hline Medium low technology & 100 & 112 & 215 & 175 & 148 & 193 & $\mathbf{1 3 8 6}$ \\
\hline $\begin{array}{l}\text { Medium high and high } \\
\text { technology }\end{array}$ & 78 & 149 & 162 & 142 & 306 & 285 & $\mathbf{1 4 5 8}$ \\
\hline Other manufacturing & 83 & 107 & 73 & 46 & 66 & 73 & $\mathbf{6 0 2}$ \\
\hline Total & $\mathbf{3 2 9}$ & $\mathbf{6 5 6}$ & $\mathbf{6 7 8}$ & $\mathbf{5 5 3}$ & $\mathbf{7 3 1}$ & $\mathbf{6 9 4}$ & $\mathbf{4 9 1 2}$ \\
\hline
\end{tabular}

Source: Author's calculations based on data of Statistics NBS-2017

\section{Conclusion}

Technical and technological progress has been recognized as the most significant source of economic growth globally, in the long term. The most significant impetus to this growth came from changes in the structure of production in the world, shifting the focus of industries with low-tech activities to medium-high and high-tech sectors.

Rapid and massive structural changes in the industry have initiated the expansion of international trade, whose growth, after 2000, was much faster than added value and gross domestic product globally. In a very short span of time, middle and hightech products have assumed dominance in global exports. In addition to the most developed countries, from which key technical and technological innovations originated, developing countries made a significant contribution to this development of international trade. Their opening up to the world market has resulted in the 
increased dynamic of structural changes in their own industries, as well as the gradual takeover of the leading position in world exports.

After a drastic downfall in 2008, Serbia's exports have recovered rapidly, both on the EU-28 and global markets. In the period 2010-2018, commodity exports to the world grew dynamically at an average annual rate higher than the growth of world exports. In addition, exports to the EU countries have played a dominant role, in addition to the slow recovery of this large market from the effects of the global crisis. Along with slowing down import growth, the manufacturing industry made a key contribution to reducing Serbia's external imbalance.

In the post-crisis period, the relative share of exports of medium and high-tech products has been steadily increasing. However, despite the positive trend, changes in Serbia's export structure do not follow the dynamics of global change. The world average of the relative share of exports of medium and high-tech products was significantly higher.

In the observed period, all three technology groups of exported products on the EU-28 market recorded both absolute and relative growth of market share. However, the obtained results of the discovered comparative advantages trends' analysis using the modified RCA index, indicate that the growth of the competitiveness of our exports is not sufficient to increase the market share - both of individual sectors and the entire manufacturing industry.

In the post-2010 period, the more competitive export segments of Serbia, the low and medium-low tech product groups, have a marked downward trend in competitiveness. In 2018, their modified RCA index indicates, at the same time, that the export segment of medium and high-tech products had negative values throughout the period, with a growing trend of competitiveness.

The basic problems in realizing the new model of economic growth of the Republic of Serbia and strengthening the competitiveness and open comparative advantages of the manufacturing industry are related to the volume and structure of investments. The reliance on foreign direct investment inflows and the neglect of private and public domestic investments have resulted in insufficient volume of total investment and the extremely slow growth of gross domestic product and manufacturing.

In these circumstances, there were no expected rapid structural changes in the sphere of production and exports. The insight into the technological level of foreign direct investment in the period until 2017, clearly illustrates the fact that foreign investors are oriented towards investing in the low and medium-low technological level of newly installed capacities in our country. The structure of total investment is even worse, due to the low volume and outdated structure of domestic investment. 
Obviously, Serbia lacks a realistically feasible strategy for the economic growth and development of the manufacturing industry, with balanced funding sources, long-term development goals and an effective industrial policy.

\section{References}

Abramovitz, M. (1986). Catching Up, Forging Ahead, and Falling Behind. Journal of Economic History, 46(2). p. 385-406.

Balassa, B. \& Noland, M. (1989). Revealed Comparative Advantage in Japan and the United States, Journal of International Economic Integration, 2(2).

Balassa, B. (1965). Trade Liberalisation and Revealed Comparative Advantage, The Manchester School, Vol. 33, No. 2, pp. 99-123.

Ćorović, E. (2019). Strukturni problemi finansiranja privrednog rasta Republike Srbije. Novi Pazar: Naučna publikacija Državnog Univerziteta u Novom Pazaru, serija B: Društvenohumanističke nauke, Volumen 2, br. 1. p. 28-45.

Ćorović. E. (2012). Procesi deindustrijalizacije i reindustrijalizacije - savremeni pravci strukturnih promena u svetskoj privredi. Niš: Ekonomika 2/2012.

Durand M. \& Giorno C. (1987). Indicators of International Competitiveness: Conceptual Aspects and Evaluation. OECD Economic Studies 9.

Fagerberg, J. \& Srholec, M. (2008). National Innovation Systems, Capabilities and Economic Development. Research Policy, 37(9), p. 1417-1435.

Fagerberg, J. (1987). A Technology Gap Approach to Why Growth Rates Differ. Research Policy, $16(2-4)$. p. 87-99.

Fertö, I. \& Hubbard, L. J. (2003). Revealed Comparative Advantage and Competitiveness in Hungarian Agri-Food Sectors, The World Economy, 26(2).

Gligorijević, Ž. \& Ćorović, E. (2018). Ekonomika industrije, Novi Pazar: Državni univerzitet u Novom Pazaru.

Gligorijević, Ž. \& Ćorović, E. (2019). Strukturne promene i novi model rasta Republike Srbije. Niš: Ekonomski fakultet.

Hatzichronoglou, T. (1997). Revision of the High-Technology Sector and Product Classification, OECD Science, Technology and Industry Working Papers, No. 1997/02.

Helleiner G.K. (1991). Increasing International Competitiveness: A Conceptual Framework. In: EDI Seminar Series Increasing the International Competitiveness of Exports from Carribean.

International Monetary Fund (IMF), (2016) World Economic Outlook: Subdued Demand, p. 63.

Jefferson Institute. (2003). Konkurentnost privrede Srbije 2003, Beograd.

Jefferson Institute. (2006). Konkurentnost privrede Srbije 2006, Beograd.

Kovačević, M. (2010). Uzroci niskog nivoa i mere za povećanje konkurentnosti privrede Srbije, Kako povećati konkurentnost privrede i izvoza Srbije, Naučno društvo ekonomista i Ekonomski fakultet Beograd, Zbornik radova.

Krugman P. \& Hatsopoulos G.N. (1987). The Problem of U.S. Competitiveness in Manufacturing. New England Economic Review, January/February.

Mićić, V. (2016). Strukturne promene i konkurentnost privrede republike Srbije, Kragujevac, Unapređenje konkurentnosti privrede Republike Srbije, Zbornik radova, Ekonomski fakultet u Kragujevcu, str. 61-69.

Narodna banka Srbije - Statistika 2017.

OECD. (2003). OECD: Science, Technology and Industry Scoreboard 2003. Paris.

Porter, M. (1990). The Competitive Advantages of Nations, McMillan, London and Basingstoke.

Republički zavod za statistiku. Statistički godišnjak 2012-2018. 
Reza, S. (1983). Revealed Comparative Advantage in the South Asian Manufacturing Sector: Some Estimates, Indian Economic Journal 31(2). p. 96-106.

Savić, Lj., (2002) Ekonomika industrije, Beograd: Ekonomski fakultet.

Službeni glasnik RS 55/2011. (2011). Strategija i politika razvoja industrije Republike Srbije 2011-2020.

Topcu, B.A. \& Kilavuz, E. (2012). Revealed comparative advantage and competitiveness of the turkish manufacturing sector in the European market, International journal of economics and finance studies Vol 4, No 2/2012.

UNIDO. (2013). Industrial Development Report 2013, Vienna.

UNIDO. (2016). Industrial Development Report 2016, Vienna.

UNIDO. (2018). Industrial Development Report 2018, Vienna.

United Nations Statistics Division. (2002). New York.

Verspagen, B. (1991). A New Empirical Approach to Catching Up or Falling Behind. Structural Change and Economic Dynamics, 2(2), p. 359-380.

Veselinović, P. \& Makojević, N. (2016). Izvori finansiranja kao ograničavajući faktor privrednog razvoja Srbije, u: Unapređenje konkurentnosti privrede Republike Srbije, Kragujevac: Ekonomski fakultet.

World Bank, http://data.worldbank.org/indicator/NE.EXP.GNFS.ZS/countries.

World Economic Forum, (2018) The global competiveness Report 2012-2013, Geneva.

Y1lmaz, B. (2003). Turkey's Competitiveness in the European Union: A Comparison with Five Candidate Countries - Bulgaria, The Czech Republic, Hungary, Poland, Romaniaand the EU15, Ezoneplus Working Paper, No.12, February.

\section{OTKRIVENE KOMPARATIVNE PREDNOSTI I KONKURENTNOST PRERAĐIVAČKE INDUSTRIJE REPUBLIKE SRBIJE}

Apstrakt: Ključna istraživačka pitanja u ovom radu vezana su za utvrđivanje efekata i uticaja novog modela privrednog rasta na komparativne prednosti i konkurentnost izvoza tehnoloških grupa proizvoda prerađivačke industrije Srbije na tržištu EU-28. Prilikom istraživanja korišćeni su neki od analitičkih instrumenata metodologije razvijene od strane Međunarodnog trgovinskog centra (ITC), kao i modifikovani RCA indeks. Izvršena je komparacija rezultata merenja konkurentnosti izvoza primenom pomenute metodologije i RCA indeksa po formuli Balassa. Sve relevantne analize dale su slične zaključke u pogledu skromnih efekata reformisanog modela rasta, niskog nivoa konkurentnosti izvoza proizvoda srednje visoke i visoke tehnologije, ali i u pogledu zaostajanja Srbije u odnosu na konkurente iz neposrednog okruženja i svetski prosek. Dobijeni rezultati upućuju na zaključak da Srbija nije uspela da izbalansira strukturu izvora finansiranja novog modela privrednog rasta, posebno, u smislu nedovoljne zastupljenosti domaćih, javnih i privatnih, investicija. To se odrazilo na nizak obim bruto investicija, a posebno investicija $u$ industriju, njihovu neadekvatnu strukturu i spor rast izvoza proizvodnih sektora koji su najviše zahvaćeni tehničkotehnološkim progresom.

Ključne reči: Prerađivačka industrija, RCA indeks, tehnološke grupe, konkurentnost, investicije. 


\section{Authors' biographies}

Enes Ćorović is an Assistant Professor at the State University of Novi Pazar, Department of Economic Sciences, Republic of Serbia. Born on 21.04.1957. in Novi Pazar. He completed his basic and postgraduate studies at the Faculty of Economics in Belgrade. He defended his doctoral dissertation in the field of economic development and economic policy at the Faculty of Economics in Niš. Until 2010, he worked as Managing Director of the largest social and private textile factories. From 2010, at the SUNP, until he was elected Assistant Professor in 2016, he worked in the following positions: Associate at the Research Center, Associate in Teaching and Assistant with a Ph.D. He has published several scientific papers in domestic and foreign journals.

Živorad Gligorijević, PhD, Full Professor at the Faculty of Economics in Nis, was born on October 14, 1954 in Nevada, Kursumlija municipality. He graduated from the Faculty of Economics in Niš. He completed his postgraduate studies at the Faculty of Economics in Belgrade. He defended his doctoral dissertation in the field of economic development and economic policy at the Faculty of Economics in Niš. He has been working at the Faculty of Economics in Niš since june 1st. 1980. He teaches at basic academic studies (subjects: Industry Economics, Industrial Management and Tourism Economics), master studies (subject: Regional Economics), as well as doctoral studies (subject: Industrial Economics). He is the author of many scientific papers of both national and international importance, as well as numerous monographs and textbooks.

Aleksandar Mansijević was born on 05.02.1997. in Leskovac. He finished elementary and high school in Medvedja. He enrolled at the Faculty of Economics in Nis in 2015 and he is a student of final year of basic academic studies. During his studies he participated in numerous projects and competitions, of national and international importance, where he achieved significant results. He is the founder and director of the Student Science and Research Center of the Faculty of Economics in Nis and editor of the collection of student papers "Regional Development and Demographic Flows". His area of interest is regional development and regional policy. He has published about a dozen scientific papers in this field. 